\title{
1. Innovating European Labour Markets: An Introduction
}

\author{
Ton Wilthagen, Ruud Muffels, Peter \\ Ester and Joop Schippers
}

\subsection{INTRODUCTION}

It is not a big secret that when politicians and policymakers are speaking of 'challenges' they are actually referring to severe problems that are very difficult to handle. The labour market is such an area of challenges or, phrased differently, large problems. It represents a societal domain where, in the words of the Portuguese social theorist De Sousa Santos (1995), we are facing modern problems but are lacking modern solutions. Moreover, there is an awareness, fed by a classical sociologist such as Durkheim (1960) and a modern economist such as Sen (1985), to mention just two of them, that the labour market as a domain is a major vehicle for social integration, cohesion, wealth and well-being creation, and the distribution thereof. This implies that when labour markets are not operating properly this not only creates problems of 'function', that is problems in the labour market itself, but also problems of 'performance', that is negative effects on the society at large. ${ }^{1}$

The aims of this book are to portray and examine the ongoing changes in employment forms and people's life courses and particularly to present, put to the test and further develop innovative labour market policies and perspectives. The policies and perspectives can be considered potential answers to the challenges and requirements labour market and employment systems confront. It is in this manner that we can define the key concept of 'innovation', namely as adequate and effective, possibly even proactive, responses to these challenges and requirements.

We will now further elaborate on the typical paradoxes and challenges in modern societies and labour markets in particular (Section 1.2), present the policy and scientific perspectives (Section 1.3) and from there on elucidate the themes and the structure of this book (Section 1.4). 


\subsection{PARADOXES AND CHALLENGES}

The mammoth tasks at hand for European, national and local labour markets and employment systems can further be conceptualised and summarised by using Talcott Parsons' well-known analytic AGIL model (Adaptation, Goal Attainment, Integration and Latency) which he designed for analysing all types of collectivities (Parsons and Smelser, 1956). This model shows the four basic functions that all social systems should perform in order to survive.

The first function is adaptation which pertains to the necessity of obtaining sufficient resources and advantages, in particular in economic production and competition. Companies - employers, workers, other stakeholders and shareholders - are key actors here. Both external and internal labour markets are crucial in providing the mechanisms for optimally allocating, using and developing resources - human and nonhuman - to guarantee flexibility and timely adjustment to changing market circumstances and to warrant high levels of productivity and performance.

The second function is called goal attainment and it deals with the problem of setting goals and effectively implementing policies and strategies - in our case concerning labour market and employment goals and policies. Governments, social partners, collective bargaining parties, inspectorates and European agencies are the main players here, responsible for designing and mapping out innovative and effective strategies that facilitate and support individuals and companies in their development and risk management, keeping a specific eye on weaker groups in the labour market.

Thirdly, there is the function of integration, referring to the problem of preserving security, cohesion, solidarity and coordination within the system, preventing segmentation and exclusion in the labour market. The 'integrative' agencies required from this perspective are the same actors as under goal attainment with the addition of courts and social security and social policy organisations.

The fourth and final function is called latency and points at the issue of creating, preserving and transmitting the distinctive culture and values within the system. Training and education organisations and institutions play a prominent role here and the school to work transition represents an example of a crucial period. People's preferences in working lives, such as working time and retirement preferences, are another major aspect of latency in the realm of the labour market. The latency issue is rather pressing from a European point of view, as it touches upon the current debate whether the European Union can provide and preserve a distinctive European Social Model, based on a set of European values. 
The current challenges to labour market and employment systems are a neat illustration of the more general paradoxical tension that we can observe in European societies. Part of these challenges originate from tendencies that we can label 'converging pressures', or, in the words of Pierson (1998), 'irresistable forces', that is the development of new interdependencies that increasingly expose workers, companies, sectors and national governments to 'global' or common conditions. Globalisation, the integration of markets with the EU internal market as a prominent example - increased international competition, labour migration and, though varying across countries and continents, demographic developments such as ageing and decreasing workforces are all aspects of this tendency (Giddens, 2007). Other challenges, on the contrary, result from tendencies that can be characterised as forms of diversification or divergence. Major manifestations here are the increasing diversity in work-related preferences and choices, in labour market transitions, in patterns of working, working time and caring, in educational trajectories, including risks of mismatches between education, skills and labour demand, in career paths and, finally, in overall life courses (Van den Heuvel et al., 2004). These work-related diversities are also related to the larger variation in consumer behaviour and consumption patterns.

The paradoxical nature of this twin set of challenges evidently influences the way that they can be addressed. 'Global' tendencies generally require forms and efforts of coordination, whereas divergent tendencies generally call for diverse policies, decentralisation and a tailor-made approach. The current state of the European Union illustrates that both coordination and decentralisation are indispensable - causing a kind of acrobatic 'split' - and that striving for a 'unity in diversity' seems to be the best way forward (Silva Peneda and Albino De Rossa, 2006). We can label this interdependence the coordination-decentralisation nexus, which represents, in essence, a governance issue.

On the national and European level policy responses towards this nexus have been developed, with the European Commission's 2001 White Paper on European Governance as a very good case in point. ${ }^{2}$ These policy responses are inspired by the academic debates and scientific theory formation on multi-level regulation (Léonard, 2001; Sisson and Marginson, 2002), coordinated or controlled decentralisation (Traxler, 1994, 2003), actorcentered institutionalism (Mayntz and Scharpf, 1995; Scharpf, 1997; Van Lieshout, 2008) and reflexive law and governance (Teubner, 1993; Rogowski and Wilthagen, 1994; Rogowski, 2007).

In a practical way, some of the current and urgent major labour market challenges and problems Europe faces can be summarised as follows, reflecting issues of adaptability, goal achievement, integration and latency: ${ }^{3}$ 
- A major challenge for the European Union is how to combine inclusive with highly productive labour markets. Although employment rates have recently increased in the EU, coupled with a drop in unemployment over the last three years, unemployment is still too high in most Member States and unevenly distributed. Particular categories of the population, that is the young, women, older workers, minorities and third country nationals, continue to suffer much higher unemployment risks and unfavourable working and living circumstances, such as discrimination and limited access to social security and other arrangements.

- At the same time over a million unfilled job vacancies exist, reflecting a severe mismatch between labour supply and labour demand. Labour mobility, migration and the posting of workers across the borders of EU Member States has accelerated in recent years, providing on the one hand possible resources for resolving labour market shortages, but at the same time producing a new economic, social and cultural issue in both the host and donor or home countries of these workers.

- There is underinvestment in lifelong learning by all actors concerned. Compared to the EU's main competitors (depending on which EU countries are taken into account), there is also a considerable productivity gap both in terms of productivity per worker and productivity per hour worked.

- Moreover the adaptability of European companies needs to be further enhanced to successfully deal with global competition, while at the same time providing new and more dynamic securities to workers. It is crucial that not merely current risks but also future risks are addressed, as the needs for flexibility and security can and do vary across the life course and the business cycle.

- The trust of European citizens in future employment opportunities, in the development of human capital, in decent work and labour market developments urgently needs to be strengthened, while companies require a supportive business climate and a transparent and predictable legal framework in order to increase business potential and create employment.

- More effort is needed to hit the EU target agreed in 2006 for every young person who has left school or university and becomes unemployed to be offered a job, apprenticeship, training or other employability measures within 100 days.

- Early school leaving is a particularly severe problem among immigrants and minorities.

- Gender gaps remain wide, both in terms of wages and career opportunities. Availability of affordable child care is a problem in a 
number of Member States, which makes it more difficult to reconcile work and private life.

- Member States have put some effort into increasing the labour market participation of older workers, but more is needed to create real job opportunities for them. The sustainability of pension schemes is at stake and at risk in many of the EU Member States.

We now turn to policy views and academic perspectives that have been developed in response to these challenges and issues.

\subsection{POLICY VIEWS AND ACADEMIC PERSPECTIVES}

In this section we briefly introduce the innovative policies and perspectives that have inspired many of the contributions in this book. It will become clear that the demarcations between the policy responses and the scientific responses are, although visible, not always very strong. In the field of labour markets and employment issues, policymaking and academic approaches, although bound by their own rationalities and goals, are often characterised by a strong mutual influence. Much of the relevant academic work in the field has been picked up rather rapidly by policymakers, evidently applying the concepts and evidence in their particular fashion and geared towards their own needs and interests.

\subsubsection{The Transitional Labour Markets and the Life Course Approach}

The theory of transitional labour markets (TLM), as developed by Günther Schmid (Schmid, 2000; Schmid and Gazier, 2002) from the mid 1990s onwards, responds, in Schmid's words, to the 'requisite variety' that results from trends in modern labour markets and individuals' life courses. The basic assumption of the theory reads that 'the borders between the labour market and other social systems have to become more open for transitory states between paid work and gainful non-market activitities, which preserve and enhance future employability'. This is expected to result in a new form of full employment, as 'the institutionalisation of transitional labour markets would encourage mobility ("transitions") across the border of social systems without inducing downward spirals of social exclusion by optimising people's lifetime social participation' (Schmid, 2000, pp. 223-4). As such the TLM approach forms a life-course-oriented view on the interactive relationship between (external and internal) labour markets and other socially productive domains, including private households, education, non-work activities and retirement. The transitions included in the model are best seen 
as status transitions. They do not necessarily require full-blown 'sequential' transitions, but can also be analysed in term of people's combinations of activities within the various domains. A core distinction is between 'good transitions', which contribute to people's empowerment in the labour market and 'bad transitions' (or 'dead end street transitions', which limit opportunities). The main policy implication of the TLM approach is formulated as 'make transitions pay', that is reduce the institutional, organisational and cultural barriers and social and financial disadvantages for people to move (to and from) between the different social spheres and the labour market by offering them transition opportunities and facilities. A life course perspective is being advocated by Schmid when he argues that working hours could vary across the individual's life course, depending on the stage of life, resulting for example in an average of 30 hours per working week on a lifetime basis. During the transitional periods it would offer employment opportunities to others.

In general the life course literature is multidisciplinary, including disciplines such as sociology, economics, psychology, demography and biology. Notwithstanding the differences, these research lines share the fact that they all add an explicit temporal dimension to human behaviour and development. ${ }^{4}$ Early conceptualisations of the life cycle were influenced by the Darwinian theory of evolution and concentrated on the process of social reproduction, and in psychology also on socialisation and the psychological development. In the 1960s and 1970s, neoclassical economists designed dynamic models to account for individuals' inter-temporal choices, for example between work and leisure time, bringing different tastes and preferences into the focus. More recently, the rational choice framework was related to aspects as the inherited social capital as well as social and individual welfare. Norms, traditions and institutions are core elements in understanding individual behaviour over the life course, as it is a person's 'habitus', as Bourdieu and Giddens have argued (see Adams, 2006). Neoclassical economists have come up with different assumptions about how the future affects current decisions through the way agents discount the future. However, the question how the past influences current decisions was often ignored. It was not until the 1990s that social scientists (for example Mayer, 2000; Elder et al., 2003) started considering the life course as a whole, acknowledging the importance and consequences of early transitions for later decisions and events.

In our view, theoretically speaking, life course arrangements and policies acknowledge that, from the individual workers' perspective, his or her different activities in a certain life phase have to be reconciled; in particular paid work has to be combined with other social activities at a given moment. This can be called a first level of synchronisation. The workers' wishes and 
potentials can differ according to his/her sex, age, education, family context, interests and so on. At the same time a life course policy has to deal with the diachronisation (that is synchronisation through time) and the follow-up of different life-phases throughout the life course of individuals, since the individual worker's situation is not stable, but can change over the life course.

Explicit life course policies have been absent until recently. Today the life course perspective is clearly visible in European labour market and social policy (; Klammer et al., 2006; Muffels et al., 2008; Klammer, forthcoming). The increasing interest in education and training propelled by the concepts of 'lifelong learning' and of an 'investive social policy' are clear signs of this new perspective. The emphasis on the development of a 'knowledge-based society' demands long-term strategies. The goals of the Lisbon strategy to increase the labour market participation of older workers and the actual retirement age (Barcelona and Stockholm targets, see European Commission, 2003) have also contributed to the need to focus on work biographies, on long-term employability of workers and on sustainability in labour market participation. Accordingly the European Directives for the national action plans explicitly state: 'this requires developing comprehensive national strategies based on a life course approach' (Council of the European Union, 2003, Paragraph 15).

Integrated Guideline no. 18 of the European Employment Strategy ${ }^{5}$ asks the Member States of the EU to promote a life-cycle approach to work through:

- a renewed endeavour to build employment pathways for young people and reduce youth unemployment, as called for in the European Youth Pact,

- resolute action to increase female participation and reduce gender gaps in employment, unemployment and pay,

- better reconciliation of work and private life and the provision of accessible and affordable childcare facilities and care for other dependants,

- $\quad$ support for active ageing, including appropriate working conditions, improved (occupational) health status and adequate incentives to work and discouragement of early retirement,

- modern social protection systems, including pensions and healthcare, ensuring their social adequacy, financial sustainability and responsiveness to changing needs, so as to support participation and better retention in employment and longer working lives. 
In the current proposal by the European Commission for the 2008-2010 Guidelines the text of Guideline 18 is similar to the 2005 version. However, references to the life-cycle approach are now being made under more Guidelines.

Moreover, in some countries specific life course arrangements have emerged in recent years. Between 2001 and 2002 in the Netherlands a number of reports and articles were published, mainly initiated by the Ministry of Social Affairs and Employment, resulting in an 'Exploring the life course' (Verkenning levensloop) report in 2002 and a comprehensive annex containing examples of and barriers to a life course approach. These studies ultimately resulted in the introduction of the Life Course Saving Arrangement (levensloopregeling) by law in 2006.

Another example of a life-course-oriented scheme is the Belgian career break/time credit system, that came into force in 1985 and that was extended by the Flemish government in 1994. This scheme entails a fiscal measure that allows people to flexibly reduce their working hours or exit their job without any restriction as to the underlying motive (see Román et al., 2006 and also Chapter 12 of this book). Finally, working time accounts can be considered to be yet another type of life course arrangement, which can be observed in various countries.

\subsubsection{The Flexicurity Approach}

Traditionally, policies aimed at enhancing security are of a reactive nature, that is they follow, usually with a significant delay, the political recognition and assessment that a lack of security exists or that developments in or outside the labour market are harmful to the security of certain groups. In turn, flexibilisation policies are usually launched, also after some delay, to adjust labour market or social security arrangements and institutions that are considered too 'tight', protective or static and presumed to hamper economic development, dynamism and competitiveness.

In many Western welfare states job and social security systems (employment protection, social protection, unemployment and disability insurance, welfare schemes) developed after the Second World War, generally reaching their 'completion' in the late 1960s and 1970s. The 1980s, however, following economic and budget crises, can be typified as an era where deregulation and privatisation appeared as the dominant political concepts. In the course of the 1990s policy scientists started to notice that the 'deregulation versus regulation' or 'flexibility versus security' debate might be positioned and conceptualised too narrowly. Institutional and regulatory settings in the labour market are no longer seen as mere economic barriers. Rather, certain settings and forms of (re)regulation are considered conducive 
to economic performance (Streeck, 1992). Social policy is increasingly being typified as as a 'production factor' and social institutions are either perceived as 'harmless' with regard to economic growth, or are thought to matter in a positive sense (see Auer, 2001). As Esping-Andersen and Regini (2000, p. 340) put it in their book with the meaningful title Why Deregulate Labour Markets?: 'Managing unemployment is greatly facilitated when, and if, the social partners are capable of strong coordination and consensus-building.'

This scientific debate has led to the observation of European labour markets as displaying yet another nexus, which has been referred to as the flexibility-security nexus (Wilthagen and Rogowski, 2002; Wilthagen and Tros, 2004). The quest for a new (dynamic) equilibrium, facilitating and enhancing the adaptability and capacity to deal with the change of both individuals and companies has come to be labelled 'flexicurity' (Wilthagen, 1998). Flexicurity is defined as a policy strategy to enhance, at the same time and in a deliberate way, the flexibility of labour markets, work organisations and employment relations on the one hand, and security - employment security and social security - on the other (Wilthagen and Tros, 2004). From a theoretical point of view flexicurity policies can be characterised as a form of coalescence and synchronisation of economic and social policy (Wynn, 2000, p. 501) or as a post-deregulation strategy (Keller and Seifert, 2000, p. 293).

The flexicurity concept has met with much acclaim and criticism after becoming a key policy concept within the European Employment Strategy, as documented, in particular, by the adaptation of Common Principles on flexicurity by the European Council on 5 December $2007,{ }^{6}$ the report and resolutions on flexicurity from the European Parliament on 29 November $2007,{ }^{7}$ the joint labour market and flexicurity analysis presented by the European social partners on 18 October $2007,{ }^{8}$ the Communication on flexicurity by the European Commission dated 27 June $2007^{9}$ and the much debated Green Paper on the Modernisation of Labour Law issued 22 November $2006 .^{10}$

All in all, a European policy framework has now been established, more or less, and it is now up to the Member States of the EU to make flexicurity work in a decent and constructive way. According to the European Commission and the European Expert Group on Flexicurity (2007) the current socio-economic challenges require a more flexible labour market combined with satisfactory levels of security to respond simultaneously to the new needs of employers and employees. New forms of flexibility and security are needed, for individuals and companies, to be provided by the Member States and the Union as a whole. Individuals increasingly need employment security, to complement job security, as fewer workers have a job for life. 
Flexicurity, as an integrated policy strategy, should address many of these issues at the same time. Its objective is thus to combine employment and income security with flexible labour markets, work organisation and labour relations. This approach transcends the simple trade-off between flexibility and security, where the former is seen to be in the exclusive interest of the employer and the latter in the interest of the employee. The key principle that underpins a flexicurity strategy is that flexibility and security should not be seen as opposites, but can be made mutually supportive. Flexicurity strategies should set off from a win-win perspective, based on trust and highlydeveloped industrial relations.

Flexicurity could best be seen as a system of joint and mutual risk management for workers and employers (Evers and Wilthagen, 2007). Employers face the risk of a weakening market position due to increased competition, but also the risk of a quantitative and qualitative mismatch of labour supply as a result of technical progress, demographic change and varying preferences and competences among workers. For workers, job or employment security and the possibility of reconciling work and private life may be at risk due to business responses to globalisation and intensified competition. Therefore joint and mutual risk management is needed. Contributing to the risk management of the other party contributes to managing one's own risks.

A flexicurity approach should also take account of the long-term, dynamic relationship between flexibility and security needs and preferences. From the flexicurity approach it is important to stress that a longitudinal view does not only concern individuals. Perspectives of different social and institutional actors have to be considered, notably those of companies, addressing the coordination between companies' business cycles and their employees' life cycles. Business cycles have become shorter and less predictable. They are not necessarily congruent with the workers' time horizons. Companies have to adjust to fluctuations in market demands and with the overall need to warrant and enhance competitiveness. Thus, a second arena of synchronisation - business needs versus individual needs - can be identified, adding to the synchronisation necessity that was perceived already within the transitional labour market and life course perspectives. Moreover, the business process itself can also be seen as a synchronisation process, that is as an endeavour to fine-tune market demands and production means and capacities. Finally, as not only individuals but also businesses have a need for diachronisation processes (across the respective business cycle and life cycle) there exists an ultimate need for synchronising these diachronisation processes. 


\section{Regimes and pathways}

Considering the wide differences in country practices and challenges, the EU rightfully does not believe in a one-size-fits-all approach. Rightful, because the existing evidence derived from the welfare regime (Esping-Andersen, 2002; Muffels, 2007) and Varieties of Capitalism literature (for example Hall and Soskice, 2001) convincingly suggest that countries' policies seem to follow their own national routes. There is also little or no evidence from empirical research that due to internationalisation and globalisation pressures these policy regimes signal a strong trend of convergence over time across the various policy routes. These routes are based on historical social, political economic and cultural roots and heritage making them strongly pathdependent without suggesting that there are no common features or that transferability of policies are inconceivable and that regimes are unable to learn from each other. On the contrary, regimes might learn from 'best practices' in other countries but it does not need to imply that they depart strongly from their original roots rather than staying largely on their original tracks. Various contributions in the book use or refer to the regime type approach providing evidence about the performance of the various regimes in Europe to balance flexibility and security goals in their respective societies. The idea of pathways as brought forward recently very much hinges on the view that there are different roads with similar levels of success or unsuccess in attaining high or low levels of flexibility and security (for example Muffels, 2008). The concept of flexicurity pathways also suggests different roads countries can take to improve their labour markets, based on different challenges, priorities and possibilities. Another reason is related to the 'subsidiarity principle' of the EU, implying that the Commission also has to respect the autonomy that each Member State has regarding their national labour market and social policies. For these reasons the EU has recently proposed (in its Communication on flexicurity) a set of flexicurity pathways, based on the work of the European Expert Group on Flexicurity (2007), addressing different challenges and possible solutions in Member States.

Flexicurity pathways can be designed and implemented across four policy components, as defined by the European Commission, which in her view need to be taken into account as a whole:

1. flexible and reliable contractual arrangements;

2. efficient active labour market policies (ALMP) to strengthen transition security;

3. systematic and responsive lifelong learning (LLL);

4. modern social security provisions that also contribute to good mobility in the labour market. 
Moreover, a supportive and productive social dialogue between all stakeholders and a highly developed trust-based industrial relations system in a country serve as general preconditions or process variables to make such a flexicurity system work. That is, at least, what the Danish flexicurity model has taught us (Jørgensen and Madsen, 2007).

The ideal-typical flexicurity pathways, which could inspire Member States in setting their own flexicurity agenda, are the following:

\section{Flexicurity pathway 1: dealing with flexibility at the margin}

The first pathway addresses the issue of flexibility at the margin of the labour market. It suggests reducing asymmetries between standard and non-standard work by promoting upward transitions in the labour market and by integrating non-standard contracts fully into labour law, collective agreements, social security and lifelong learning systems. Non-standard contracts are then treated as equal to standard contracts, following the principle of pro rata temporis. Alternatively, standard contracts could be made more attractive to companies by introducing an open-ended contract in which specific elements of protection are built up progressively with time, until 'full' protection is achieved. Such a contract guarantees basic but adequate protection from the start and automatically builds up 'full' protection as the working relationship continues. Social partners and governments should negotiate the terms of these arrangements.

\section{Flexicurity pathway 2: securing transitions from job to job}

The second pathway emphasises safe and successful job-to-job transitions. Built-in contractual guarantees and HRM policies should ensure timely progress into new jobs either within the company or outside the company once the necessity arises. Furthermore, it may be feasible to introduce individualised transition guarantees to redundant workers, to be borne jointly by employers, social partners and public employment services in order to prevent unemployment. A strong system of lifelong learning and vocational training may form the basis for productive labour market transitions both inside and outside companies. Such a system should allow for quick access to effective training funds and facilities at branch level. Within this pathway, strengthening internal flexicurity is also relevant, especially to enhance the employability and skills of workers.

\section{Flexicurity pathway 3: access to learning and good transitions for all}

This pathway recommends strengthening, on the basis of existing levels of labour market dynamism, investment in skills and R\&D. The employment and security opportunities and options of specific groups in the labour market can thereby be enhanced and productivity growth boosted. A broad-ranging 
approach is needed to keep the labour market accessible to the low-skilled and other groups at risk, such as minorities, older workers, women and the early school leavers, of becoming long-term unemployed or excluded in other ways. Flexicurity will benefit from the possibility to conclude binding agreements at branch or regional level that combine provisions on how to address the flexibility needs of both employers and workers by investment in training. Where the institutional structures for such agreements are not yet in place, support from the social partners and government is needed.

Flexicurity pathway 4: comprehensive social security supporting transitions to regular work

This pathway starts from the urgent need to increase the employment and job opportunities of persons who are currently on social security benefits or working in the informal sector. ALMP and social security should offer sufficient opportunities and incentives, in terms of increased conditionality of benefits, to return to work and to facilitate this transition. Long-term welfare dependence could thus be prevented. Informal work can be regularised by offering flexi-secure contracts, lower payroll taxes and a skills perspective for these sectors. By formalising informal economic activities, increased financial resources can be raised for building up a more comprehensive social security system. Stronger institutional capacity needs to be developed by stimulating the social partners to negotiate key elements of working conditions and by better cooperation between labour market and benefit institutions. Social dialogue can be further developed at sector and regional level and both bipartite and tripartite dialogue can be strengthened.

\subsection{OUTLINE OF THE BOOK}

As stated already, this volume deals with three areas of labour market issues, which we have related in the introduction to the functions of labour market systems on the basis of Parson's AGIL scheme. The first part deals with transitional labour markets and focuses on labour market changes and policies dealing with the external labour market, the second concerns flexicurity and working time flexibility issues within internal labour markets and the third part deals with life course transitions and careers focusing on labour market dynamics and policies concerning the life course. Each part discusses certain problems and challenges as well as innovative solutions to resolve them.

In the part on transitional labour markets the first contribution (in Chapter 2 ), is by Vandenbroucke, minister of education, training and employment in the Flemish region of Belgium. Vandenbroucke combines a vast experience 
in labour market policymaking with a solid scientific background. His contribution focuses on both the necessity and the directions for labour market innovation, comparing and benchmarking Flanders to the Netherlands, the Nordic countries and the EU average. The typical labour market problems pertaining to Belgium are characterised by Vandenbroucke as a so-called compressed career model, that is people enter the labour market at a relatively high age (due to education trajectories) and retire rather early. During this fairly short spell workers are highly productive but also suffer from feelings of exhaustion. Labour market participation in the older age groups is quite low compared to EU standards. Another major issue regards, as in many other European countries, the phenomenon of outsiders in the labour market, notably older people, immigrant groups and low-skilled persons. According to Vandenbroucke innovative labour market policies should urgently enhance dynamism and need to break two 'vicious circles': (1) low economic productivity of the older age cohort, paralleled with high productivity of the middle-age cohort, resulting in high work pressure; (2) prejudices in the labour market against immigrants lead to weak incentives among these groups to invest in study and training, resulting in deficits in education and competencies, which, in turn, produces a self-fulfilling prophecy in that employers are less willing to employ these groups.

In Chapter 3 Fouarge and Ester address another key aspect of external flexibility in the labour market, namely transnational mobility or labour migration. In the current scientific and policy debate labour migration is considered both a solution, solving labour shortages in tight labour markets with insufficient national labour supply, and a potential problem in the sense that it might lead to crowding out effects, underbidding, brain drain and, all in all, to social dumping and a race to the bottom with regard to labour and social security standards. Whereas the European Commission strongly favours and encourages cross-border mobility, the earlier discussions on the EU service and posting directives and, very recently, the rulings of the European Court of Justice in the Laval, ${ }^{11}$ Viking ${ }^{12}$ and Ruffert ${ }^{13}$ cases have caused quite a stir and a lot of concerns notably among unions. Yet, until recently not much was known about migration intentions and decisions across the EU and their determinants. Fouarge and Esther contribute to this knowledge, deriving rich data from the 2005 Eurobarometer Mobility Survey.

Cazes and Nesporova report, in Chapter 4, on labour market challenges, dynamics and flexibilisation in Central and Eastern European countries. The current debate on labour market reform and flexicurity tends to be biased towards the North-Western part of Europe. Moreover, there is a lack of acknowledgement of the variety within the Central and Eastern 'cluster' of countries, which actually does not appear to be a coherent cluster in the line 
of Esping-Andersen's famous typology of welfare states. From a scientific and policy point of view studies that consider the flexibility-security nexus in transition economies are highly relevant, as they can shed more light on the economic, institutional, legal and political preconditions for reconciling dynamism, stability and security. The aim of the chapter is to investigate, from a comparative perspective, whether in the light of new economic and labour market developments since the end of the 1990s new tendencies have also become manifest in labour mobility, its fluctuation across the economic cycle as well as in flexible forms of employment.

In the last contribution within this section Muffels, in Chapter 5, uses empirical comparative data to examine the performance of Western European countries in balancing flexibility and security goals for men and women separately. He uses the European Community Household panel to cover 13 countries during the period 1994-2001. He defines gender-based dynamic indicators on flexibility translated into a measure of occupational and contract mobility and on income and employment security to map countries and regime types on the way they seem capable of balancing flexibility and security goals. He also tries to examine the separate effects of labour market institutions on how they affect males' and females' transition patterns such as active labour market policies, employment protection legislation and the generosity of social security benefits. The chapter provides evidence on the success of various policy pathways and of the effect of specific institutions on the levels of flexibility and security in society and therewith can teach us about the salient effects of particular policy pathways and measures.

The second part of the book focuses on the employment relationship at the company level and deals with flexicurity practices and innovative working time arrangements established within companies, that is within the internal labour market, but with a proper perspective on the company's environment. Marsden's contribution in Chapter 6 takes as a starting-point the open-ended employment relationship, for many decades now the standard and wellestablished contractual form for combining great flexibility and a large degree of enforceability. Despite the fact that statistical indicators do not indicate a decline of this type of employment regulation, in certain sectors, such as the media and creative industry, a 'network economy' is emerging. This employment system is featured by project organisation and project and team work. Marsden's interest lies in exploring the challenge posed by firm's need for greater use of more transient forms of employment relations. $\mathrm{He}$ does so by assessing the three types of 'contract' - psychological, economic and legal - that constitute and consolidate the open-ended contract. Subsequently the author examines in what way and to what extent network employment can provide equivalents for these contracts and could possibly inspire labour market or HRM innovations. 
In Chapter 7 Kerkhofs, Chung and Ester deal with working time flexibility, an essential form of internal numerical flexibility and adaptability as well as a key mechanism for synchronising the domain of paid labour with the private household sphere. Using the Establishment Survey in Working Time and Work-Life Balance, conducted in 21 European countries, they develop a typology of European companies based on the use and provision of working time arrangements and work-life balance facilities and the characteristics that determine these profiles. In particular the authors examine the degree to which organisations combine flexibility measures that support their operational needs with arrangements supporting and facilitating the employees' work-life balance.

Vermeylen in Chapter 8 maps out the mix of various dimensions of flexicurity - forms of flexibility and security - in the European Union, taking stock of various research projects initiated by the European Foundation for the Improvement of Living and Working Conditions and the Foundation's 4th European Working Conditions Survey. After discussing the driving forces behind the flexicurity concept, gaining a particular momentum in recent years, and the policy debate at the European and national level she investigates in detail and from a comparative perspective the different flexibility strategies (numerical, temporal, functional) that companies apply, the role of social institutions in warranting security, also in view of new social risks, and the importance of trust and the involvement of all relevant actors in developing a flexicurity model.

The contribution by Wotschack and Hildebrandt in Chapter 9 concentrates on an instrument, long-term working time accounts, that might, in an innovative way, contribute to enhancing internal flexibility in companies while simultaneously supporting individual workers' life courses by preventing or addressing discontinuities. With the latter aspect the chapter provides an introduction to the third overarching theme of the book, that is the life course. The analysis is based on a 2005 survey among German companies. The quintessence of long-term working time accounts is that hours of work provided in advance or in excess constitute availability for an equivalent number of hours of paid leave at a later point in time. Basically two forms of long-term working time accounts have emerged. On the one hand optional accounts have been created which are used during the course of the working life with withdrawals at selected points in time and for various personal purposes, and age-related accounts with take-up possibilities limited to the end of the working life (as a type of early retirement or pension provision) on the other hand. The authors point out that the diffusion of long-term working time accounts needs to be understood in the light of several related but at the same diverging tendencies in the labour market and in labour market policymaking. 
As indicated, the life course is the topic of the third major theme of the book. This part starts with a contribution, in Chapter 10 by Schmid, the intellectual author of the concept of transitional labour markets. The core thesis of this approach, as formulated by Schmid, is that the quality of life is determined to a significant extent by people's possibility to participate in working life as long as they wish and at the same time on the opportunities they have to combine paid work with other self-determined activities. The chapter puts the emphasis on 'active aging', identifying its conditions and criteria. From a comparative view, the differences in performance by European Member States are being assessed with regard to the labour market participation of older workers in European Member States. Finally, the chapter reflects on the key aspects of positive and innovative policy strategies that increase the options for transitions from the second to the third lifephase. Among these key aspects are: the necessity to differentiate institutions according to requisite variety (that is responding to varying situations and preferences), notably by transforming unemployment insurance into a worklife insurance, the application of the normative principle of risk-sharing through an egalitarianism based on responsibility and capability, the principle of decoupling social security from discontinuities over the life course and the principle of negotiation to overcome trade-offs between flexibility and security.

Brzinsky-Fay in Chapter 11 takes as a starting-point the early stage in the life course where people make the transition from school to work, a critical stage that has a huge impact on the opportunities available in the future course of the employment and labour market career. The school-to-work transition should provide a fair amount of security in terms of employment prospects, but also allow for sufficient flexibility regarding training opportunities and the matching of individual preferences and market requirements. The objective of the study is to identify different types of school-to-work transition sequences in European countries, going beyond the study of single situations or status changes (that is one transition at a time). Thus the integrative and risk character of the entire process of labour market entry can be assessed more adequately. This more long-term approach can be an impetus for active labour market policies that currently target problem groups, such as migrant and early school leavers, that face higher risks of labour market exclusion. The longitudinal dataset used for the analysis is the European Community Household Panel.

In Chapter 12 Román, Schippers and Heylen argue that the process of individualisation is creating a diversification of life course patterns. Paid work may still have a central but not per se a predominant position within these patterns. Facilities and arrangements have been developed with the aim of enabling people to combine work with other responsibilities. There is, 
however, only scarce evidence with respect to the long-term effects of the use of these facilities. Are standard full-time working careers indeed becoming less the norm? Is there evidence of an increase in transitions to, on and from the labour market? The authors choose the Belgian labour market as a case to identify labour and career typologies using the Panel Study on Belgian Households, originating in 1992. Belgium represents an interesting case as it is among the few countries that has introduced an innovative and life course arrangement, the so-called career break system.

This book's explicit aim is to confront, in the next chapters, innovative labour market concepts and perspectives with the empirical and practical realities of the labour market, labour law, industrial relations and human resource management. It is only by this method that scientific and policy concepts can be tested and further developed and practices can be further improved.

\section{NOTES}

1. The distinction between function and performance is a key notion within the theory of social systems as developed by Parsons et al. (1951 ), Luhmann (1984) and Teubner (1993).

2. Brussels, 25.7.2001 COM(2001) 428 final.

3. This overview is based on the report of the European Expert Group on Flexicurity (2007), the European Commission's study on Europe's social realities (2007) and the joint analysis of labour market challenges and flexicurity undertaken by the European social partners (European Social Partners, 2007).

4. This first paragraph is based on Klammer et al. (forthcoming).

5. Guidelines 2005, 2005/600/EC.

6. 16201/07, SOC 523 ECOFIN 503.

7. $2007 / 2209$ (INI).

8. 'Key challenges facing European Labour Markets. A Joint Analysis of the European Social Partners', www.etuc.org/a/4119.

9. COM (2007) 0359.

10. COM (2006) 708 final.

11. ECJ C-341/05, 18 December 2007.

12. ECJ C-438/05,11 December 2007.

13. ECJ C-346/06, 3 April 2008.

\section{REFERENCES}

Adams, M. (2006), 'Hybridizing habitus and reflexity: towards an understanding of contemporary identity', Sociology, 40 (3), 511-28.

Auer, P. (ed.) (2001), Changing Labour Markets in Europe. The Role of Institutions and Policies, Geneva: International Labour Office.

Council of the European Union (2003), 'Council Decision of 22 July 2003 on guidelines for the employment policies of the Member States', Official Journal of the European Union, 5.8.2003, L 197 13-L 19721. 
De Sousa Santos, B. (1995), Toward a New Common Sense. Law, Science and Politics in the Paradigmatic Transition, New York: Routledge.

Durkheim, E. (1960), The Division of Labour in Society, New York.

Elder, G.H., Johnson, M.K. and Crosnoe, R. (2003), 'The Emergence and Development of Life Course Theory', in Mortimer, J.T. and Shanahan M.J. (eds), Handbook of the life course, New York: Springer, pp. 3-19.

Esping-Andersen, G. and Regini, M. (eds) (2000), Why Deregulate Labour Markets?, New York: Oxford University Press.

Esping-Andersen, G. (2002), Why we Need a New Welfare State, Oxford: Oxford University Press.

European Commission (2001), European Governance. A White Paper, Brussels.

European Commission (2003), 'The Stockholm and Barcelona targets: Increasing employment of older workers and delaying the exit from the labour market', Commission Staff Working Paper, SEC (2003) 429, Brussels.

European Commission (2007), Europe's Social Reality, Bureau of Economic Policy Advisors (BEPA) document (February).

European Social Partners (2007), 'Key challenges facing European Labour Markets. A joint analysis of the European Social Partners', www.etuc.org/a/4119.

Evers, G. and Wilthagen, T. (2007), De toekomst van de arbeidsrelatie: een essay over wederkerig risicomanagement (The future of the employment relationship: an essay on mutual risk management), Assen: Van Gorcum.

Giddens, A. (2007), Europe in the Global Age, Cambridge: Polity Press.

Hall, P. and Soskice, D. (eds) (2001), Varieties of Capitalism: The Institutional Foundations of Comparative Advantage, Oxford: Oxford University Press.

Jørgensen, H. and Madsen, P.K. (2007), Flexicurity and Beyond. Finding a New Agenda for the European Social Model, Copenhagen: Djøf Publishing.

Keller, B. and Seifert, H. (2000), 'Flexicurity - das Konzept fur mehr soziale Sicherheit flexibler Beschaftigung', WSI Mitteilungen, 53 (5), 291-300.

Klammer, U., Keuzenkamp, S., Cebrián, I., Fagan, C., Klenner, C. and Moreno, G. (2006), Working Time Options over the Life Course: Changing Social Security Structures, Luxembourg: European Foundation for the Improvement of Living and Working Conditions, Office for Official Publications.

Klammer, U., Muffels, R. and Wilthagen, T. (forthcoming, 2008), Flexibility and Security over the Life Course. Key Findings and Policy Recommendations from the Foundation Research, Dublin: European Foundation for the Improvement of Living and Working Conditions.

Léonard, L. (2001) 'Industrial relations and the regulation of employment in Europe', European Journal of Industrial Relations, 7, 27-47.

Luhmann, N. (1984), Soziale Systeme, Frankfurt am Main: Suhrkamp Verlag.

Mayer, K.U. (2000), 'Promises fulfilled? A review of 20 years of life course research', Archives Européennes de Sociologie, XL (12), 259-82.

Mayntz, R. and Scharpf W.F. (1995), 'Der Ansatz des akteurzentrierten Institutionalismus', in Mayntz, R. and Scharpf F.W. (eds), Steuerung und Selbstorganisation in staatsnahen Sektoren, Frankfurt am Main: Campus, 39-72.

Ministry of Social Affairs and Employment (the Netherlands) (2002), Verkenning levensloop (Exploration of life course) report. The Hague.

Muffels, R., Chung, H., Fouarge, D., Klammer, U., Luijkx R., Manzoni, A. and Wilthagen, T. (2008), Flexibility and Security Over the Life Course: Results and Policy Implications, Luxembourg: European Foundation for the Improvement of Living and Working Conditions, Office for Official Publications. 
Muffels, R. (2007), 'Roads of "flexicurity" in Europe: how (un)equal are they?', in Jørgensen, H. and Madsen, P.K. (eds), Flexicurity and Beyond. Finding a New Agenda for the European Social Model, Copenhagen: Djøf Publishing, pp. 21543.

Muffels, R. and Luijkx, R. (2008), 'Male labour market mobility and income and employment security in Europe', in Muffels, R. (ed.), Flexibility and Employment Security in Europe: Labour Markets in Transition, Cheltenham, UK and Northampton, MA, USA: Edward Elgar, pp. 133-168.

Parsons, T., Shils, E.A. and Tolman, E.C. (1951), Toward A General Theory of Action, Cambridge, MA: Harvard University Press.

Parsons, T. and Smelser, N.J. (1956), Economy and Society: A Study in the Integration of Economic and Social Theory, London: Routledge and Kegan Paul.

Pierson, P. (1998), 'Irresistable forces, immovable objects: post-industrial welfare states confront permanent austerity', Journal of European Public Policy, 5 (4), 539-60.

Rogowski, R. (2007), 'Flexicurity and reflexive coordination of european social and employment policies', in Jørgensen, H. and Madsen, P.K. (eds), Flexicurity and Beyond. Finding a New Agenda for the European Social Model, Copenhagen: Djøf Publishing, pp. 131-53.

Rogowski, R. and Wilthagen, T. (eds) (2004), Reflexive Labour Law: Studies in Industrial Relations and Employment Regulation, Deventer, Cambridge: Kluwer Law and Taxation.

Román, A., Heylen, L. and Schippers, J. (2006), Career Breaks In Belgium: How They Affect Labor Participation and Individual Careers, Tilburg: OSA.

Scharpf, F.W. (1997), Games Real Actors Play. Actor-centered Institutionalism in Policy Research, Boulder/Cumnor Hill: Westview Press.

Schmid, G. (2000), 'Transitional labour markets: a new European employment strategy', in Marin, B., Meulders, D. and Snower, D. (eds), Innovative Employment Initiatives, Aldershot, UK: Ashgate, 223-53.

Schmid, G. and Gazier, B. (eds), (2002), The Dynamics of Full Employment: Social Integration Through Transitional Labour Markets, Cheltenham, UK and Northampton, MA, USA: Edward Elgar.

Sen, A. (1985), Commodities and Capabilities, Amsterdam: North Holland, reprinted by Oxford University Press, Delhi.

Silva Peneda, J. and Albino De Rossa, P. (2006), A European Social Model for the Future, Brussels: European Parliament Report.

Sisson, K. and Marginson, P. (2002) 'Co-ordinated bargaining: a process for our times?', British Journal of Industrial Relations, 40, 197-220.

Streeck, W. (1992), Social Institutions and Economic Performance, London etc.: SAGE Publications.

Teubner, G. (1993), Law as an Autopoietic System, London: Blackwell.

Traxler, F. (1994), 'Collective bargaining: levels and coverage', in OECD, OECD Employment Outlook 1994, Paris: OECD, pp. 167-94.

Traxler, F. (2003), 'Coordinated bargaining: a stocktaking of its preconditions, practices and performance', Industrial Relations Journal, 34, 194-209.

Van den Heuvel, N., Van der Hallen, P., Van der Lippe, T. and Schippers, J. (eds) (2004), Diversity in Life Courses: Consequences for the Labour Market, Tilburg: OSA.

Van Lieshout, H. (2008), Different Hands: Markets for Intermediate Skills in Germany, the U.S. and the Netherlands, Groningen: Hanzehogeschool Groningen. 
Wilthagen, T. (1998), Flexicurity: A New Paradigm for Labour Market Policy Reform? Berlin: WZB Discussion Paper FS I 98-202.

Wilthagen, T. and Tros, F. (2004), 'The concept of "flexicurity": a new approach to regulating employment and labour markets', Transfer, 10 (2), 166-86.

Wilthagen, T. and Rogowski, R. (2002), 'Legal regulation of transitional labour markets', in Schmid, G. and Gazier, B. (eds), The Dynamics of Full Employment: Social Integration through Transitional Labour Markets, Cheltenham, UK and Northampton, MA, USA: Edward Elgar, pp. 233-73

Wynn, M. (2000), 'European social dialogue: harmonisation or new diversity?', in Collins, H., Davies, P. and Rideout, R. (eds), Legal Regulation of the Employment Relation, London/Dordrecht: Kluwer Law International, pp. 491-511. 
Ton Wilthagen, Ruud Muffels, Peter Ester and Joop Schippers - 9781781007723

Downloaded from Elgar Online at 05/12/2020 08:42:08AM 